\title{
ENGLISH TEACHING PRACTICES AND INTERCULTURAL ISSUES
}

\author{
Nicoleta-Mariana IFTIMIE* \\ "Gheorghe Asachi” University of Iaşi, Romania
}

\begin{abstract}
Saying that English has become a language of global communication has become a truism. Some of us may wonder: Why English? Why not another language? The reasons that brought about its status as a lingua franca are many, but the main ones have to do with the growth of the British Empire and its expansion as a colonial power, England's economic development as a result of the Industrial Revolution and America's growth as an economic and scientific power in the post-war era. Communication in English has expanded to multiple settings that include native-to-native, native to nonnative and nonnative to nonnative interactions. As a result, the new role of English as a language of international communication shared by people with different national and cultural backgrounds has brought to the fore discussions regarding the neat relationship between a particular language and a particular culture, which was for a long time one of the central tenets of foreign language education. Thus, the concept of one language has been challenged by the multilingual nature of English in various countries, which brought about the concept of new Englishes. The idea of one culture, on the other hand, has been challenged by the multinational and multicultural nature of the English speaking community, spread all over the globe. The article examines the global spread of English and discusses its implications for teaching practices, which need to cater for the dimension of intercultural communication set against global issues of standardization and intelligibility and local issues connected to a specific social, cultural and educational context. The analysis is based both on the theoretical issues dealt with in the literature and on the author's own experience as a teacher of English in Romania and abroad.
\end{abstract}

Keywords: English as a lingua franca, English as an International Language, Kachru's concentric circles model, Communicative Language Teaching, culture-sensitive methodology

\footnotetext{
*nicoletaiftimie@yahoo.co.uk
} 


\section{INTRODUCTION}

People have always tried to communicate with one another across countries and borders. Various languages have played the role of lingua franca, facilitating communication among men in various parts of the world at different moments in history: old Greek, Latin, Arabic, Spanish, Portuguese, French, Russian. None of these languages has acquired the international status English has acquired since the last decades of the $20^{\text {th }}$ century, i.e., that of the prevailing language used in transnational scientific, political, business and educational communication all over the world. As Jenkins (2003) and Kirkpatrick (2007) point out, English has performed a shift from a language used for intranational purposes to an international medium of communication. It is used nowadays not only for native-to-native communication, but also in contexts that require nonnative-tonative or nonnative-to-nonnative interactions (Crystal1997; Graddol 2006). Estimates show that about 2 billion people have knowledge of English (Graddol 2006). This number is predicted to grow to over 3 million by 2050 (British Council 2004; cited inWardhaugh 2006: 379). As Crystal (2001) claims, "English is now spoken by more people (as a first, second, or foreign language) than any other language and is recognized by more countries as a desirable lingua franca than any other language" (54). Moreover, statistics results show the speakers of English as a second or foreign language outnumber that of the English native speakers (McKay 2002; Jenkins 2006; Kirkpatrick 2007). Consequently, the new role of English as a language of international communication shared by people with different national and cultural backgrounds has questioned the validity of the traditional assumption regarding the neat relationship between a particular language and a particular culture which was for a long time one of the central tenets of foreign language education. Thus, the concept of one language has been challenged by the multilingual nature of English in various countries, which brought about the concept of new Englishes. The idea of one culture, on the other hand, has been challenged by the multicultural nature of the English speakers and users, spread on all continents.

The spread of English and the emergence of new Englishes have brought to the fore questions regarding the ad litteram transfer of language teaching methods and strategies based on first language acquisition assumptions to those who learn English as a second or foreign language in different classroom and cultural contexts. This article examines the spread of English and its implications for teaching practices in countries where English is taught as a second or foreign language. The discussion is based both on theoretical issues dealt with in the literature and on the author's own experience as a teacher of English in Romania and abroad. 


\section{THE SPREAD OF ENGLISH: KACHRU'S MODEL AND LATER DEVELOPMENTS}

Probably the best-known representation of the spread of English is given by Kachru's tripartite model of concentric circles (1985), which represent "the types of spread, the patterns of acquisition and the functional domains in which English is used across cultures and languages" (12). Thus, the inner circle includes countries such as the UK, the USA, Canada, Australia, or New Zealand, in which English is the native or first language; the outer circle countries are former colonies in which English has gained special status in administration and is learned as a second language (India, Singapore, Malaysia, the Phillipines, Nigeria); finally, there are the expanding circle countries, in which English is learned as a foreign language (Brazil, South Korea, Japan, China, Russia, Romania). In Kachru's view, the three circles are differently related to the norms of English: thus, the inner circle countries are norm-providing, the countries in the outer circle are norm-developing, while the expanding circle countries are norm-dependent. Later, Kachru revisited this tripartite distiction and reduced it to a dichotomy: norm-providing users are those using English as L1 or L2 (the inner and the outer Circle users), while norm-dependent users are those in the expanding circle (China, Taiwan, Egypt, Korea, etc.).

Like all attemps that try to encapsulate reality in a model, Kachru's paradigm has both pluses and minuses, which are presented in a synthetic manner in Table 1 below.

Table 1 Kachru's Model:Pluses and Minuses

\begin{tabular}{|l|l||}
\hline \multicolumn{1}{|c|}{ Pluses } & \multicolumn{1}{|c|}{ Minuses } \\
\hline $\begin{array}{l}\text { It offers a diachronic view of } \\
\text { the spread of English. }\end{array}$ & It oversimplifies things. \\
\hline $\begin{array}{l}\text { It accounts for the function } \\
\text { and status of English in } \\
\text { various regions of the world. }\end{array}$ & $\begin{array}{l}\text { It doesn't account for } \\
\text { some areas (South Africa, } \\
\text { Jamaica). }\end{array}$ \\
\hline $\begin{array}{l}\text { It provides a framework for } \\
\text { the study of world Englishes. }\end{array}$ & $\begin{array}{l}\text { The inner circle countries } \\
\text { are at the centre, while the } \\
\text { others occupy a rather } \\
\text { peripheral position. }\end{array}$ \\
\hline & $\begin{array}{l}\text { It maintains a divide } \\
\text { between us and them. }\end{array}$ \\
\hline & $\begin{array}{l}\text { It is based on historical } \\
\text { events, rather than on } \\
\text { sociolinguistic data. }\end{array}$ \\
\hline
\end{tabular}


The main strengths of Kachru's tripartite model are the following: it offers a diachronic view of the spread of English and accounts for the function and status of English in various parts of the world, while providing a framework for the study of world Englishes.

However, the model has some limitations: this tripartite classification oversimplifies things by providing clear-cut distinctions and does not take into account the grey areas between the circles. This makes it difficult to find a proper place for countries such as South Africa or Jamaica. Another drawback of the model has to do with the somewhat biased, Anglocentric view it offers: the inner circle countries are placed in the centre, while the expanding circle countries occupy a peripheral position (Graddol 1997; Rajadurai 2005). Graddol (1997) claims that this positioning may suggest that the inner circle should be regarded as "the source of models of correctness, the best teachers and Englishspeaking goods and services consumed by those in the periphery" (10). In an article published in 2005, Rajadurai remarks

[i]t is ironic then that the tri-circle model inadvertently reinforces the concept of the native speaker as the centre of reference, thus promoting a form of linguistic imperialism and language hegemony that Kachru was determined to avoid (114).

By positioning the native speakers in the centre, as source of knowledge and correctness for the speakers of English in the other circles, Kachru creates a divide between norm-providing and norm-dependent and thus maintains the dichotomy us and them, which his model tried in fact to eliminate.

Kachru's model has been followed by other attempts in which the dichotomy native-nonnative is replaced by various levels of proficiency in English as an International Language. Three such models will be discussed here: the model proposed by Modiano (1999), the one suggested by Melchers and Shaw (2003) and the tentative model offered by Rajadurai (2005). Modiano develops a "centripetal circles model" (Rajadurai 2005:121) in which the inner circle is populated by all competent users of English as an International Language (EIL), be they native or non-native; the native speakers of regional dialects who are not capable of "global appropriacy" are relegated to the second circle, together with nonnative speakers of indigenized varieties; the outer circle includes those who are not proficient in any variety of English. Using the same criterion as Modiano, i.e. individual proficiency, Melchers and Shaw place the speakers of English on four levels: 1) those who are internationally effective; 2) those who are nationally effective; 3 ) those who are locally proficient; 4) those who are ineffective. Rajadurai offers a tentative three-circle model based on 
proficiency levels in EIL ${ }^{1}$ : the inner circle would include both native and nonnative proficient users of English; the second circle consists of "speakers who are proficient only in regional varieties, i.e. native and nonnative speakers with restricted intranational proficiency" (Rajadurai 2005:124); the outer circle includes learners of English.

Although these new models are not without weaknesses and may raise many questions, they have the advantage of being more flexible and less native speaker-centred as compared to Kachru's paradigm. Flexibility comes from the fact that speakers of English are not confined to one and the same circle for ever: as (and if) their proficiency increases, they will gradually move to the inner circle, which can thus expand to accommodate the newcomers. Another strength is represented by the classification criterion: nativeness, historical and geographic factors are replaced by a single criterion, that of individual proficiency that erases the former distinction between native and non-native speakers.

\section{ENGLISH AS AN INTERNATIONAL LANGUAGE}

Given the fact that there are so many languages in the world, a question comes to our mind: which are the factors that make a certain language (in our case English) become an international means of communication? In trying to answer this question, Crystal (1997) discards quantitative factors (such as the number of individuals speaking it as a native language) or intellectual reasons (languages that can be seen as vehicles of High Culture or outstanding civilization). In his view, there are two main factors that account for the use of a certain language as a medium of international communication: power (mainly military or political power, sometimes also religious power) and economic strength. English makes no exception: its rise to the status of international language can be seen as a consequence of its former colonial dominance in many parts of the world, as well as a result of the economic development that started with the Industrial Revolution and continued with the technological advances in the UK and USA in the $20^{\text {th }}$ century.

There are two opposite types of discourse that try to explain the dominant position of English in world communication: one sees its rise to the status of global language as a natural historical and cultural outcome (Crystal 1997; Wardhaugh 1987); the other points out the interdependence between the worldwide use of English and political, ideological, economic and commercial interests of the inner circle countries, mainly the UK and USA. Various voices in

\footnotetext{
${ }^{1}$ EIL is defined by Rajadurai as "English used across national boundaries", irrespective of whether it is used by native or non-native speakers (Rajadurai, "Revisiting the concentric circles: Conceptual and sociolinguistic considerations”, 2005, p. 123.
} 
the literature, starting with Phillipson and his seminal book Linguistic Imperialism (1992) and continuing with Pennycock (1994, 1998) and others, have argued that the rise (and continuation) of English to the status of world language is the result of a deliberate effort to promote the economic and commercial interests of the UK and USA across countries and nations. Therefore, far from being a natural outcome, a matter of being 'in the right place at the right time' (Fennel 2001: 244), the spread of English appears in such a view as the result of linguistic and cultural imperialism. According to such a view, the British and American educational organizations and research agencies that promote cooperation, cultural and educational goals promote the foreign policy and economic interests of the countries they represent. The English language is thus traded "like a commodity" (Ciprianová \& Vančo 2010: 123) by means of the language training market offered by such educational organizations and agencies with the help of a growing ESL and EFL textbook market.

These types of discourse have given birth to different views on English as an International Language: 1) the neutral view; 2) the imperialist view; 3) the democratic view; 4) the pragmatic (functional) view.

The neutral view. As shown above, the worldwide spread of English has resulted in a fast growing number of speakers of English in the outer and expanding circles, so that at present the nonnative users of English (those who speak English as a second or foreign language) outnumber the native speakers. Many local and regional 'new Englishes' or 'world Englishes' have developed in various parts of the world (Indian English, Singapore English, East Asia English, etc). Therefore, the more English is used across various cultures and borders, the less it can be said to be 'owned' by native speakers. The ownership of English tends to become de-territorialized, "de-nationalized" (Smith 1976), or rather, as McKay (2002: 12) puts it, "re-nationalized" by nonnative speakers belonging to the outer and expanding circles. As such, English is no longer tied to one culture and, as a result, EIL attains a certain degree of neutrality. As Wardaugh puts it, "since no cultural requirements are tied to the learning of English, you can learn it and use it without having to subscribe to another set of values" (Wardaugh 1987: 14-15). According to this view, English appears to be a means of communication between people of many first languages deprived of any attachment to a particular culture or a particular set of values.

The imperialist view. According to this view, supported among others by Phillipson (1992) and Pennycook (1998), English is "a clear expression of political, cultural, and economic imperialism" (Wardhaugh 2006: 380). These authors consider that English has reached its position of lingua franca due to its imperialist past and it continues to serve the economic, cultural and academic interests of the inner circle countries, especially USA and the UK. Moreover, there are authors who point out the threat EIL has represented for the indigenous cultures and languages, going as far as to call it a 'killer language' 
(Mühlhäusler 1996). An argument to such claims is brought by Pennycook, who argues that English "is constantly replacing other languages in daily use and school curricula" (2001: 81). Along the same lines, those who support the imperialist view consider that EIL promotes social inequalities, due to the fact that "[English] has become one of the most powerful means of inclusion into or exclusion from further education, employment or social positions" (Ibid.).

The democratic view. English is perceived as more 'democratic' than other languages, French included, due to its lack of honorifics and culturally attached forms of address. You, for example, effaces the difference between informal, formal and neutral ways of address. The supporters of this view argue that proficiency in EIL has opened up new opportunities, as it offers access to economic, scientific, and cultural-educational worldwide interactions. Thus, according to Graddol (1997: 51), 84\% of the world's electronic information is in English. Moreover, a significant percentage of the scientific papers in various fields, such as biology, physics, medicine, chemistry and mathematics are in English, which shows that EIL offers unlimited access to scientific information all over the world. As the dominant language in many world organisations, English "plays a vital role in the participation of larger political and educational institutions" (Nicholson 2015: 17). Thus, in Phillipson's opinion (2008: 250), International English is described as "a lingua economica" (a medium for business dealings or international trades), a "lingua academica" (a medium for content learning and academic publications), a "lingua cultura" (a medium for cultural exchange or intercultural communication), to name a few. This use of English in international business, cultural and academic interactions in many expanding circle countries is part of its functional or pragmatic role. Such a pragmatic role is played in many parts of the world: South Korea, China, Taiwan, Eastern and Central European countries, etc.

\section{GLOCALIZING ELT: EAST AND WEST}

The global spread of English has important consequences for teaching practices, which need to cater for the dimension of intercultural communication set against general issues of standardization and intelligibility and local issues related to language variations and the host culture complex. Holliday (1994) views the classroom as a complex web of cultures: first, there are the students and their reference group (friends and family) with their previous language learning experience and expectations; then, there are the teachers and their reference group (colleagues), with their own language learning experience, training and professional education, teaching experience and teaching philosophy; the materials used, their content and inherent methodological approach; the publishers and libraries; the host institution; the host educational environment; the local and national professional-academic culture; the national culture; the 
international related cultures. Therefore, the classroom milieu it is "part of a complex of interrelated and overlapping cultures of different dimensions within the host educational environment" (Holliday 1994: 28). Cortazzi and Jin (1996) also speak about a 'culture of learning' which shows that
[...] much behavior in the language classroom is set within a taken-for- granted framework of expectations, attitudes, values, and beliefs about what constitutes good learning, about how to teach or learn, whether and how to ask questions, what textbooks are for, and how language learning relates to broader issues of the nature and purpose of education (169).

Given the complexity of such socio-cultural, educational and axiological factors, Holliday (1994) argues that "any methodology in English language education should be appropriate to the social context within which it is to be used" (1-2). This means that English teaching practices should be glocalized.This new clipping compound combines the idea of the international flow of goods, ideas, culture with the need to take into account and act according to the local context. When the host cultural and educational environment are ignored, problems usually appear due to inappropriate materials or as a result of teaching methods or approaches that do not suit the local context.

In what concerns textbooks and other materials, publishers and teaching practitioners know that certain topics should be avoided because they are considered taboo (politics, religion, alcohol, drugs), because they sound disturbing in certain cultures or because they tend to reinforce national, ethnic, gender or age stereotypes. Coursebooks generally offer what might be called a complete sanitation, in that they completely discard topics that are in contradiction with the students' traditions, religious beliefs, values and lifestyle. Instead, they tend to include content areas that promote 'inclusiveness' with regard to women, or formely disregarded races, ethnic groups and cultures. However, many if not most English teaching materials used in expanding circle countries are written by native speakers of English, mostly British and American. Although such books claim to be international in content and the 'characters' that populate them belong to various nationalities and ethnic groups (Europeans, Asians, Afro-Americans, Hispanics), the cultural background is mostly Anglo-American. The conversations presented occur generally between native and nonnative speakers, the latter visiting the UK or USA as tourists, students or business people. Of course, it would be impossible for one such coursebook to cater for all existing cultures in the world. However, attempts have been made lately to devise coursebooks and other materials that take into account the culture and lifestyle the students come from. While solving the problem of local appropriateness, these textbooks need to cater for the multicultural nature of EIL. This demonstrates how hard it is to devise English 
textbooks capable to keep the right balance between global demands and local needs - between standardization and multiculturalism on the one hand and local appropriacy on the other.

Another important aspect has to do with methodology and teaching styles, which need to be adapted to the host culture of learning. Problems may occur when local teachers try to implement ad litteram methods that were developed for other cultures of learning or when native teachers try to transfer to other countries and educational contexts methods that go well in the inner circle countries, without taking into account the specific values, traditional pedagogies, the students' language learning experience and their expectations.

This is particularly the case with Communicative Language Teaching (CLT). Its uncritical implementation in certain parts of Asia (Japan, Korea, China, Hong Kong, Taiwan, Vietnam) has failed to produce the expected results. Thus, although the communicative approach started to be implemented in Hong Kong in the early 1980's, at the special recommendation of the Ministry of Education, research findings show that the results were not the ones expected. Commenting on such research findings, Tong (2004) concludes that "[a]lthough the CLT has been popular in some parts of the world, [...] its effectiveness in Hong Kong is in doubt" (199). In Vietnam "the attitude to the communicative approach is still one of ambivalence" (Le 2004: 5). The reasons for the problems encountered in various Asian countries when trying to implement CLT are numerous and pertain to the cultural, institutional and individual level: respect for authority, exam-oriented teaching, teachers who are perceived as transmitters of knowledge, traditional teaching and learning styles. At the individual level, there is still a strong belief in the efficacy of the grammar-translation and audiolingual approaches; moreover, local teachers may sometimes feel less confident in their own oral communication skills and, consequently, focus more on reading and grammar in order to feel safe. Problems have also been signalled by native teachers of English when trying to implement Western methods in other countries, without taking into account the host culture of learning. Simpson (2008) describes the cultural clashes and conflicts that arise in Chinese EFL classrooms as a result of "divergent educational philosophies" (381). The article points out that the uncritical transfer of Western methods to other countries without consideration for the local educational culture may lead to frustrations and baffled expectations for both the foreign teacher and the students.

Holliday (1994) considers this problem is rooted in the differences between the integrationist academic structure based on cooperation, process and discovery-oriented learning specific to Western culture and the collectionist education culture built on hierarchy, teacher's authority and product-oriented learning specific to many Asian and African countries.The Chinese culture of learning is considered to put emphasis on memory, imitation, and repetition. Cortazzi and Jin (1996) point out the discrepancy between the Western teachers' 
and the students' perceptions on expected learner behavior, as well as the beliefs that inform such views. While Western teachers value student volunteering in class and consider it a proof of interest and active participation, Chinese students view this as showing off. Group discussions and other group activities are seen by native teachers as important for developing interaction and promoting student-centered activities, while Asian students seem to consider them rather pointless and a waste of time.

The Chinese perspective on learning seems to be a direct consequence of the strong influence of Confucian ideas and values. Flowerdew and Miller (quoted in Mc Kay 2002) contrast the characteristic features of Chinese and Western lectures and consider that their differences are due to different sets of values. Thus, Confucian values show respect for the authority of the lecturer. As a consequence, the lecturer should not be questioned or interrupted, as these are considered signs of disrespect. In Western culture, on the other hand, where the lecturer is viewed as a facilitator or a guide, questions or even other opinions are welcomed, as they are considered a sign of interest. The Confucian trend of thought emphasizes the importance of hard work and modesty or selfeffacement, while the Western way of thinking regards as important the desire for individual development, self-confidence and self-expression. The Chinese approach to learning is group-oriented and student motivation comes from family and pressure to excel. The Western approach to learning, on the other hand, emphasizes individual development and creativity.

These differences are presented in a synthetic form in Table 2 below:

Table 2 The dichotomic view on Chinese and Western cultures of learning

\begin{tabular}{|l|l|}
\hline Chinese culture of learning & \multicolumn{1}{|c|}{$\begin{array}{c}\text { Western culture of } \\
\text { learning }\end{array}$} \\
\hline \hline $\begin{array}{l}\text { Collectionist academic } \\
\text { structure based on hierarchy, } \\
\text { teacher's authority and } \\
\text { product-oriented learning }\end{array}$ & $\begin{array}{l}\text { Integrationist academic } \\
\text { structure based on } \\
\text { cooperation, process and } \\
\text { discovery-oriented } \\
\text { learning }\end{array}$ \\
\hline $\begin{array}{l}\text { Volunteering an answer is is } \\
\text { seen as 'showing off' }\end{array}$ & $\begin{array}{l}\text { Volunteering an answer is } \\
\text { seen as proof of interest }\end{array}$ \\
\hline $\begin{array}{l}\text { Group work is generally seen } \\
\text { as a waste of time }\end{array}$ & $\begin{array}{l}\text { Group work is important } \\
\text { for developing interaction } \\
\text { and promoting student } \\
\text { centered activities }\end{array}$ \\
\hline \hline $\begin{array}{l}\text { The lecturer should not be } \\
\text { questioned or interrupted }\end{array}$ & $\begin{array}{l}\text { Questions and opinions } \\
\text { are welcomed }\end{array}$ \\
\hline
\end{tabular}




\begin{tabular}{|l|l|}
\hline $\begin{array}{l}\text { Hard work, modesty and self- } \\
\text { effacement are important for } \\
\text { self-development }\end{array}$ & $\begin{array}{l}\text { Self-confidence and self- } \\
\text { expression are important } \\
\text { for self-development }\end{array}$ \\
\hline $\begin{array}{l}\text { Group-oriented approach to } \\
\text { learning }\end{array}$ & $\begin{array}{l}\text { Individual development } \\
\text { and creativity }\end{array}$ \\
\hline
\end{tabular}

\section{GLOCALIZING ELT: A PASSAGE TO ASIA}

Problems such as those presented above can be avoided only if English language practitioners can call upon cross-cultural awareness and use those teaching strategies that produce effective learning outcomes in the given situation. Instead of adhering to or preaching a 'one-size-fits-all' method teachers should try to implement what Holliday (1994) calls a "culture-sensitive methodology" that: a) should be informed about what "happens in the classroom" and b) must "be sensitive to the prevailing cultures surrounding any given classroom" (161). In what follows I will discuss some of the context-specific issues I encountered as an outer circle teacher of English at a university in Taiwan and the solutions I found to those problems.

As discussed in a previous paper (Iftimie 2006), a thing that impressed me a lot while I was teaching in Taiwan was the high value attached to education and the high esteem in which teachers were held by authorities, educational institutions, local communities, parents and students. Everybody, from people situated in high positions down to those who occupy lower positions on the social scale are aware of the importance of education in the development of society and of human personality.

All non-philological students in Taiwan, irrespective of the department they belong to, are required to take a minimum of eight credits of English language training, which means that all undergraduate students learn English for two hours a week during four semesters (two years). This is in fact similar to what happens in Romania, with the exception that now, in some non-philological Romanian faculties English is studied as a compulsory subject only one hour/week during a single academic year. The skill most Taiwanese students feel more proficient is reading comprehension. Once they understand the meaning of new words, students can easily complete the required tasks, especially comprehension questions, fill-in and multiple choice exercises. Unlike Romanian students, who prefer variety, new types of texts and tasks in each coursebook unit, Taiwanese students seem to prefer uniformity - they like all units to have the same structure, because this permits them to complete tasks in advance. They are also quite good in what regards grammar accuracy, but they are less proficient when it comes to the 'productive' skills, i.e. speaking and writing. These characteristics differentiate them from Romanian students, who, 
as a result of their previous exposure to the commmunicative approach are quite fluent in speech, but make many grammar and spelling mistakes, which are more visible when it comes to writing.

Taiwanese students are hard-working, diligent, attentive and quiet in class - maybe too quiet. Although I had read about Asian students' reluctancy to volunteer answers to questions addressed to the whole class, this attitude puzzled me at first. There was almost no volunteering and no battle for the floor. When they finished completing a task, Taiwanese students simply leaned back on their chair and waited for the teacher to nominate them. When nominated, they generally gave correct and fluent answers. This state of affairs is considered specific for Asian students, who are looked upon as 'shy', more reticent to 'show off' and less willing to lose face than Western students (Chaudron 1988; Lucas 1984; Tsui 1996). There are various reasons that can account for this fact: a mismatch between my own and the students' perceptions regarding active participation; the students' past language learning experience; lack of confidence and fear of losing one's face (keeping face is very important in Chinese culture).

Based on my own experience as a teacher in Romania and on the tenets of the communicative approach, my expectation was that students should participate on a volunteer basis when they knew the answer to the teacher's questions. It came from the assumption that volunteering and active participation are signs of understanding and task fulfilment. Looking more deeply into these assumptions I realized that for me active participation meant 'visible' or overt participation: students raising hands to signal their wish to volunteer with an answer or even fighting for the floor, i.e., students trying to 'steal' turns or to take non-allocated turns. These things are not specific for students in Taiwan. Does this mean that Taiwanese students do not participate actively in class? I started to be more alert to the students' 'intake' behaviour, to their class behaviour related to the acquisition of new language. When I looked more attentively at what happened in the classroom, I noticed that, while listening to the tape, $\mathrm{CD}$ or to one of their colleagues, many students 'rehearsed' the texts they heard in a very soft voice. If their peer mispronounced a word, they would whisper the correct form, but would never speak it up on a volunteer basis. If nominated, such students would gladly provide the correct pronunciation. When the question was addressed to the whole class, though, they normally kept silent. Given this situation, I tried to find a solution that could reconcile the students' reluctance in volunteering an answer with the CLT tenet according to which overt participation is linked to language learning and the development of communicative competence. Since nominating students was in contradiction with my own beliefs as a teacher as it implied too much teacher-centeredness, I tried to create a system in which turns at talking were allocated by means of a cordless microphone that was passed on from one learner to another as an invitation to start talking. The microphone also resolved what Tong (2004) calls 
the "little voice" problem, i.e. the fact that some students spoke so softly that they were barely audible. With the help of the microphone, everything that was said could be heard. The advantages of using this indirect nominating system were multiple: a) the teacher was no longer the only centre of attention; b) students could 'allocate' turns to one another by passing on the microphone; c) all students had to pay attention because they did not know when their turn might come; d) this system introduced a note of fun (an analogy could be made with karaoke, one of the students' favourite pastimes).

However, this strategy did not solve all problems, as it did not boost the students' confidence in taking longer turns. When the microphone was handed to one of them, the student would give only a short answer and stop after that. Given the 'rehearsal' scene presented above, I realized that they needed more time and support in order to become confident. Therefore, I decided to make allowance for more pair and group work, which, in spite of the theoretical assumptions made in the literature, represented one of their favourite patterns of organization. I also tried to diversify the activities they had to carry out: information gap, problem solving, simulations, surveys, projects. Each activity was rounded off by means of some kind of report or short oral presentation made by the group's spokesperson. Although the teams remained roughly the same in terms of structure, the spokesperson changed each time a new task was given. The questionnaire that was administered at the end of a project work activity (Iftimie 2007) revealed that the respondents thought that it improved their speaking and organizing skills. They also mentioned that they became more involved in the task and more responsible for its successful completion.

\section{CONCLUSIONS}

This article has focused on the global spread of English and its effects on ELT methodology which, in an era marked by an unprecedented flow of information, goods and services, needs to cater for the dimension of intercultural communication placed against the framework of global issues and local considerations. The author discussed the basic East-West division in English language education and the inherent problems brought about by teaching practices and methods that ignore the host culture complex. Consequently, she pleaded for a culture sensitive methodology that needs to consider the complex web of relationships which becomes manifest in the classroom. Problems can be avoided if English language educators and practitioners analyze the specific features of the host culture complex in order to use methods and strategies that are appropriate for that specific culture of learning. The final part of the article shared the author's experience as a foreign teacher of English in Asia and offered solutions to some of the context-specific issues encountered there. 


\section{Works Cited}

Chaudron, Craig. Second Language Classrooms: Research on Teaching and Learning. Cambridge: Cambridge University Press, 1988. Print.

Ciprianová, Elena \& Vančo, Michal. "English in the Age of Globalization: Changing ELT Models, Restructuring Relationships”. JoLIE 3/2010, 123-135. http://www.uab.ro/jolie/2010/8_ciprianova_vanco.pdf. Retrieved on7 Feb 2018.

Cortazzi, Martin \& Jin, Lixian. "Cultures of Learning: Language Classrooms in China”. In H. Coleman (Ed.) Society and the Language Classroom, 169-206. Cambridge: Cambridge University Press, 1996. Print.

Crystal, David. English as a Global Language. Cambridge: Cambridge University Press, 1997. Print.

Crystal, David. “The Future of Englishes: Going Local”. In Burns, Anne, and Caroline Coffin (Eds.) Analysing English in a Global Context, 53-64. London: Routledge, 2001. Print.

Fennell, Barbara A. A History of English: A Sociolinguistic Approach. Oxford: Blackwell Publishing, 2001. Print.

Graddol, David. The Future of English. The British Council, 1997. Print.

Graddol, David. English next. Plymouth: The British Council, 2006. Print.

Gray, John. "The Global Coursebook in English Language Teaching.” In D. Block and D. Cameron (Eds.) Globalization and Language Teaching, 151-167. London: Routledge, 2002. Print.

Holliday, Adrian. Appropriate Methodology and Social Context. Cambridge: Cambridge University Press, 1994. Print.

Iftimie, Nicoleta-Mariana. "Tradition and innovation in the English classroom culture". Proceedings of the International Conference on Innovation and Management, Shih Chien University, Taipei, Taiwan, 1691-1704, 2006.

Iftimie, Nicoleta-Mariana."Using cooperative projects to develop language and research skills”. Proceedings of the International Conference on English Education and Inter-Discipline Learning. Shih Chien University, Taipei, Taiwan, 265-288, 2007.

Jenkins, Jennifer. World Englishes. A Resource Book for Students. London: Routledge, 2003. Print.

Jenkins, Jennifer."Current perspectives on teaching world Englishes and English as a lingua franca”. TESOL Quarterly, 40(1), 157-181, 2006. Print.

Kachru, Braj Bihari. 1985. "Standards, Codification and Sociolinguistic Realism: The English Language in the Outer Circle.” In Quirk, Randolph and Henry Widdowson (Eds.) English in the World: Teaching and Learning the Language and Literatures, 11-30. Cambridge: Cambridge University Press, 1985. Print.

Kirkpatrick, Andy. World Englishes. Implications for International Communication and English Language Teaching. Cambridge: Cambridge University Press, 2007. Print.

Le, Truong Bach. “Methodology for English as an International Language”. Teacher's Edition. September 2004, 4-11.

http://www.nzdl.org/gsdl/collect/literatu/index/assoc/HASH01a8/a7ac92fe.dir/d oc.pdf 
Lucas, Jenifer. "Communication apprehension in the ESL classroom: Getting our students to talk” [Electronic version]. Foreign Language Annals, 17 (6), 593598, December 1984.

Mc Kay, Sandra Lee. Teaching English as an International Language: Rethinking Goals and Approaches. Oxford: Oxford University Press, 2002. Print.

Melchers, Gunnel \& Shaw, Philip. World Englishes: An Introduction. London: Arnold, 2003. Print.

Modiano, Marko. "International English in the global village”. English Today, 15(2), 2228, April 1999. Print.

Mühlhäusler, Peter. Atlas of Languages of Intercultural Communication in the Pacific, Asia, and the Americas. Texts. Vol. 2. Mouton de Gruyter, 1996. Print.

Nicholson, Simon James. "English as an International Language: A Functional Role in South Korea”. Journal for the Study of English Linguistics, 2015, 3(1), 13-27, (March 2015). http://dx.doi.org/10.5296/jsel.v3i1.7201. Retrieved on 7 Feb 2018.

Pennycook, Alastair. English and the discourses of colonialism. London: Routledge, 1998.

Pennycook, Alastair. 'English in the world/The world in English'. In Burns, Anne, and Caroline Coffin. Analysing English in a global context. London: Routledge, 2001. Print.

Phillipson, Robert. Linguistic Imperialism. Oxford: Oxford University Press, 1992. Print.

Phillipson, Robert. Lingua franca or lingua frankensteinia? English in European integration and globalization. World Englishes, 27(2), 250-267, 2008.

Rajadurai, Joanna. "Revisiting the concentric circles: Conceptual and sociolinguistic considerations”. Asian EFL Journal, 7(4), 111-130. (December 2005). Print.

Simpson, Stephen T. "Western EFL teachers and east-west classroom-culture conflicts" [Electronic version]. RELC Journal, 39(3) 381-394, 2008.

Smith, Larry L. "English as an international auxiliary language". RELC Journal 7 (2), 38-43, 1976. Print.

Tong, Jimmy Woon Man. “Little voice: Students' confidence and their responses in English lessons” [Electronic version]. The Journal of Asia TEFL, 1(1), 197-212, Spring 2004.

Tsui, Amy Bik May. "Reticence and anxiety in second language learning”. In K. M. Bailey \& D. Nunan (Eds.) Voices from the Language Classroom, 145-167. Cambridge: Cambridge University Press, 1996. Print.

Wardhaugh, Ronald. Languages in competition. Dominance, diversity, decline. Oxford: Blackwell Publishing, 1987. Print.

Wardhaugh, Ronald. An Introduction to Sociolinguistics. Oxford: Blackwell Publishing, 2006. Print. 